\title{
Effect of Decreasing Water Irrigation Quantity on Growth and productivity of Flame Seedless Grapevines in Clay Soils Conditions Aisha S. A. Gaser ${ }^{1}$; Thoraua S. A. Abo EL-Wafa ${ }^{1}$ and A. M. Abd El-Hameed ${ }^{2}$ \\ ${ }^{1}$ Viticulture Dept., Hort. Res. Instit., Agric. Res. Center, Giza, Egypt \\ ${ }^{2}$ Plant Nutrition Department, Soil, Water and Environment Research Institute, Agric. Res. Center, Giza, Egypt
}

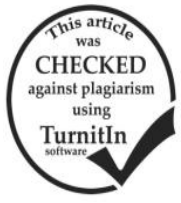

\begin{abstract}
The present investigation was carried out during three successive seasons (2015, 2016 and 2017)to determine water requirement on growth, yield and fruit quality features of Flame seedless grapevines. In Aga, Dahlia Governorate, Egypt, the chosen vines were seven years old, planted in a clay soil, spaced $2.5 \times 2$ meters apart and irrigated by flood system, spur pruned, trained to the quadrilateral cordon and trellised by the pergola system. The vines were pruned during the second week of January with bud load (56 buds/vine). The work in the first year was considered as a preliminary trial and then the experiment proceeded with the same manner during the second and third seasons, respectively. Four levels of irrigation water as follows: irrigation with $5000 \mathrm{~m}^{3} /$ Fadden (control), $4500 \mathrm{~m}^{3} /$ Fadden, $4000 \mathrm{~m}^{3} /$ Fadden and $3500 \mathrm{~m}^{3} /$ Fadden. Obtained results revealed that irrigation of Flame seedless grapevines with $4000 \mathrm{~m}^{3} /$ Fadden recorded the highest water use efficiency which it reflected in getting vegetative growth better, increasing yield/vine and improving berry quality attributes of Flame seedless grapevines in both seasons. From the obtained results, it can be recommended that Flame seedless grapevines irrigated with $4000 \mathrm{~m}^{3} / \mathrm{Fadden}$ had the best results which it gained a good yield with high fruit quality attributes.
\end{abstract}

Keywords: Grapevines, Flame seedless, irrigation, soil conditions

\section{INTRODUCTION}

Good irrigation scheduling means applying the right amount of water at the right time. Scheduling maximizes irrigation efficiency through avoiding over irrigating this often results in lower costs and optimum water use and crop yield. However, information on the applied irrigation economic amount is scarce for maximizing the crop, especially for the system, which represents approximately $50 \%$ of total vineyards cultivated area with limitations in growth, abnormal ripening and reduced berry quality. Regulated deficit irrigation can be applied as a strategy to reduce the possible negative impact of irrigation on wine quality. In Europe, irrigation tends to be reduced after verais on stage, while in Australia deficit irrigation generally is applied during the period from fruit set to verais on stage (McCarthy et al. 2000).Lovisolo et al.(2000) reported that for all the plants the pattern of water flow during the day was similar and it depended mainly on the evapotranspiration demand, but water-stressed plants always had less flow than control irrigated plants. Mean leaf surface area was $15 \%$ higher in irrigated plants. Selles et al.(2004) investigated the effect of three irrigation frequencies and the quality of grape cv. Thompson seedless at Santa, Maria the drip irrigation frequencies were established according to the daily crop evapotranspiration (ETc), estimated by pan evapotranspiration and a crop coefficient $(\mathrm{Kc})$ normally used for table grapes, which ranged from 0.25 to 0.7 . The treatments were: irrigation when the accumulated daily ETc was equivalent to 6,12 and $18 \mathrm{~h}$. of irrigation with $9.36,18.72$ and $28.08 \mathrm{~mm}$ of irrigation water (T6, $\mathrm{T} 12$ and T18, respectively).T18 recorded the highest values the different growth stages. Shellie (2005) found that vines from high water stress plots had lower yield. Abd EL-Maksoud (2009) found that increasing irrigation water decreased berry firmness and berry adherence. Nonetheless, an appropriate balance between vegetative and reproductive development (Chaves et al., 2010) is the key to improve wine grape quality in irrigated vineyards. Having a short period of water stress immediately after berry set is dependent on the soil water available at flowering time, which in turn depends on the amount of winter and early spring rains and on the water used during spring (Lopeld et al. 2011).Mohamed et al., (2016) recommended that Flame seedless grapevines irrigated at $1.0 \mathrm{ET}$ had the best results, which it gained a good yield with high fruit quality attributes.

Thus, the goal of this work is to study the effect of deficit irrigation on vegetative growth, yield and fruit quality attributes of Flame seedless grapevines under flood irrigation system.

\section{MATERIALS AND METHODS}

The present investigation was carried out during three successive seasons $(2015,2016$ and 2017)to determine water requirement on growth, yield and fruit quality attributes of Flame Seedless grapevines. In Aga, Dakahlia Governorate, Egypt, the chosen vines were seven years old, planted in a clay soil, spaced $2.5 \times 2$ meters apart and irrigated by flood system. The vines were pruned during the second week of January during the three seasons of study. Flame seedless grapevines were trained according to quadrilateral cordon using pergola trellis system and spur pruned by leaving 7 spurs with two eyes on each cordon, the total load was 56 eyes. The work in the first year was considered as a preliminary trial and then the experiment proceeded with the same manner during the second and third seasons, respectively, The experiment consisted of for treatments arranged in a randomized complete blocks design, One hundred and forty four uniform vines were chosen for this experiment ( 4 treatments $\mathrm{x} 3$ replicates $\mathrm{x}$ 12 vines/ replicate). A distance of $2 \mathrm{~m}$ was left between each two irrigation treatments to avoid the overlapping infiltration of irrigation or spraying solutions. All treatments received cultural managements as recommended by the Egyptian Ministry of Agriculture.

Treatments were conducted as follows:

1-Irrigation with $5000 \mathrm{~m}^{3} /$ Fadden/season (control)

2-Irrigation with $4500 \mathrm{~m}^{3} /$ Fadden $/$ season

3 -Irrigation with $4000 \mathrm{~m}^{3} /$ Fadden $/$ season

4-Irrigation with $3500 \mathrm{~m}^{3} /$ Fadden/season 
Aisha S. A. Gaser et al.

Table 1. Chemical and physical analysis of the experimental soil

\begin{tabular}{lc}
\hline Characters & Values \\
\hline Fine Sand \% & 15.56 \\
Coarse sand\% & 4.04 \\
Silt \% & 14.78 \\
Clay \% & 65.27 \\
Texture & Clay \\
pH $(1: 2.5)$ & 7.90 \\
O.M. $\%$ & 1.82 \\
CaCO3 \% & 1.62 \\
E.C. $(1: 5$ extract $)($ mmhos $/ 1 \mathrm{~cm})$ & 0.89 \\
N $($ ppm) & 30.63 \\
P $(\mathrm{ppm})$ & 13.72 \\
K $(\mathrm{ppm})$ & 322 \\
\hline
\end{tabular}

Table 2. The soil moisture constant (\% by weight) of the experimental soil

\begin{tabular}{lcccccccc}
\hline $\begin{array}{l}\text { Constants } \\
\text { depth } \mathbf{( c m )}\end{array}$ & $\begin{array}{c}\text { Saturation } \\
(\%)\end{array}$ & \multicolumn{2}{c}{$\begin{array}{c}\text { Field capacity } \\
(\mathbf{\%})\end{array}$} & \multicolumn{2}{c}{$\begin{array}{c}\text { Wilting point } \\
(\%)\end{array}$} & \multicolumn{2}{c}{$\begin{array}{c}\text { Available water } \\
(\%)\end{array}$} \\
& $\mathbf{1}^{\text {st }}$ season & $\mathbf{2}^{\text {nd }}$ season & $\mathbf{1}^{\text {st }}$ season & $\mathbf{2}^{\text {nd }}$ season & $\mathbf{1}^{\text {st }}$ season & $\mathbf{2}^{\text {nd }}$ season & $\mathbf{1}^{\text {st }}$ season & $\mathbf{2}^{\text {nd }}$ season \\
\hline $0-15$ & 80.6 & 80.8 & 40.4 & 40.5 & 16.40 & 16.44 & 18.58 & 19.16 \\
$15-30$ & 81.7 & 81.3 & 40.8 & 40.6 & 16.70 & 16.61 & 19.26 & 19.32 \\
$30-45$ & 82.8 & 82.5 & 41.5 & 41.4 & 16.88 & 16.82 & 20.11 & 20.03 \\
\hline
\end{tabular}

Irrigation by flooding was used from the beginning to the end of the two seasons. The total amount of irrigation by flooding at different treatment was calculated and expressed in terms of time based on the rate of water flow through the irrigation $(2 \mathrm{~L} / \mathrm{h}$.) to give such amount of water for each treatment (EC of water irrigation $0.8 \mathrm{dS} / \mathrm{m}$ ).
Irrigations number, the time and water quantity $\left(\mathrm{m}^{3}\right)$ in every irrigation are shown in Table 3.

The meteorological data represented by temperature ${ }^{\circ} \mathrm{C}$, relative humidity $(\mathrm{RH}, \%)$ and rainfall ( $\mathrm{mm} / \mathrm{month})$ for Aga Weather Station are presented

Table 3. The time (minute) and amounts of applied irrigation water $\left(\mathrm{m}^{3} / \mathrm{fed}\right.$ as well as /plot) in every irrigation during the growth period of Flame seedless via dripper lines with discharge of 2 liter $/ \mathrm{h}$. for each dripper at 0.5 bar.

\begin{tabular}{lcccc}
\hline $\begin{array}{l}\text { Water quantity } \\
\left(\mathbf{m}^{\mathbf{3}} / \mathbf{f e d}^{*}\right)\end{array}$ & $\begin{array}{c}\text { Irrigation } \\
\text { numbers }\end{array}$ & $\begin{array}{c}\text { Irrigation time in } \\
\text { every irrigation } \\
\text { (min.) }\end{array}$ & $\begin{array}{c}\text { Water quantity } \\
\left(\mathbf{m}^{\mathbf{3}} / \mathbf{f e d} \text { ) } \text { in every }\right. \\
\text { irrigation }\end{array}$ & $\begin{array}{c}\text { Water quantity } \\
\left(\mathbf{m}^{\mathbf{3}} / \mathbf{p l o t} * *\right) \\
\text { irrigation } \mathbf{~ e v e r y ~}\end{array}$ \\
\hline 5000 & 11 & 55 & 454.54 & 41.32 \\
4500 & 11 & 49 & 409.09 & 37.19 \\
4000 & 11 & 33 & 363.64 & 33.06 \\
3500 & 11 & 25 & 318.18 & 28.93 \\
\hline
\end{tabular}

Table 4. Seasonal crop water requirements $\left(\mathrm{m}^{3} /\right.$ fed) and seasonal water consumptive use $\left(\mathrm{m}^{3} /\right.$ fed) for Flame seedless grapevine

\begin{tabular}{lcc}
\hline Treatment & Seasonal crop water requirements $\left(\mathbf{m}^{\mathbf{3}} / \mathbf{f e d}\right)$ & Seasonal water consumptive $\left(\mathbf{m}^{\mathbf{3}} / \mathbf{f e d}\right)$ \\
\hline 5000 (control) & 3333.31 & 2824.84 \\
4500 & 2.941 .18 & 2492.53 \\
4000 & 2631.58 & 2230.15 \\
3500 & 4545.45 & 3852.08 \\
\hline
\end{tabular}

Table 5. Meteorological data during 2016 and 2017 seasons.

\begin{tabular}{|c|c|c|c|c|c|c|c|c|}
\hline \multirow{3}{*}{$\begin{array}{l}\text { Season } \\
\text { Parameters }\end{array}$} & \multicolumn{4}{|c|}{2016} & \multicolumn{4}{|c|}{2017} \\
\hline & \multicolumn{2}{|c|}{ Temp. ${ }^{\circ} \mathrm{C}$} & \multirow{2}{*}{$\begin{array}{c}\text { Mean } \\
\text { RH } \\
(\%)\end{array}$} & \multirow{2}{*}{$\begin{array}{l}\text { Rain } \\
\text { Fall } \\
(\mathbf{m m})\end{array}$} & \multicolumn{2}{|c|}{ Temp..$^{0} \mathrm{C}$} & \multirow{2}{*}{$\begin{array}{c}\text { Mean } \\
\text { RH } \\
(\%)\end{array}$} & \multirow{2}{*}{$\begin{array}{c}\text { Rain } \\
\text { Fall } \\
(\mathrm{mm})\end{array}$} \\
\hline & Max & Min & & & Max & Min & & \\
\hline$\overline{\text { Mar }}$ & 24.7 & 11.5 & 52.5 & 2.0 & 23.2 & 12.7 & 55.6 & 2.0 \\
\hline Apr & 27.8 & 15.1 & 49.33 & 2.0 & 25.6 & 14.8 & 52.5 & 2.0 \\
\hline May & 34.5 & 18.5 & 50.1 & 0.0 & 31.5 & 21.1 & 52.8 & 0.0 \\
\hline Jun & 40.8 & 20.8 & 51.7 & 0.0 & 39.8 & 21.8 & 53.5 & 0.0 \\
\hline July & 41.1 & 23.5 & 60.1 & 0.0 & 40.6 & 22.4 & 62.8 & 0.0 \\
\hline Aug & 41.2 & 24.6 & 65.5 & 0.0 & 44.5 & 22.6 & 66.4 & 0.0 \\
\hline Sep & 36.5 & 20.1 & 64.4 & 0.0 & 34.5 & 19.8 & 66.9 & 0.0 \\
\hline Oct & 29.5 & 15.6 & 62.33 & 0.0 & 28.6 & 15.3 & 62.8 & 0.0 \\
\hline
\end{tabular}


The Experiment started on the $3^{\text {rd }}$ week of March at 50\%(bud break stage)for the two growing seasons 2016 and 2017 by applying a heavy irrigation for all treatments. After that the suggested irrigation program concerning the frequencies and the applied quantities for the different irrigation treatments was done according to what mentioned before.

Table 6. Irrigation frequencies and dates for2016 and 2017

\begin{tabular}{|c|c|c|c|c|c|c|c|c|c|}
\hline \multirow[b]{2}{*}{ Months } & \multirow[b]{2}{*}{ Mar } & \multicolumn{4}{|c|}{ Irrigation frequencies and dates } & \multirow[b]{2}{*}{ Aug } & \multirow[b]{2}{*}{ Sep } & \multirow[b]{2}{*}{ Oct } & \multirow{2}{*}{$\begin{array}{c}\text { Total irrigation } \\
\text { frequencies }\end{array}$} \\
\hline & & Apr & May & Jun & Jul & & & & \\
\hline \multirow{2}{*}{ Seasons } & & & & Frequ & ncies & & & & \multirow{4}{*}{11} \\
\hline & 1 & 1 & 2 & 2 & 2 & 1 & 1 & 1 & \\
\hline 2016 & $22 / 3$ & $25 / 4$ & $11 / 525 / 5$ & $6 / 6-21 / 6$ & $6 / 7-23 / 7$ & $20 / 8$ & $17 / 9$ & $14 / 10$ & \\
\hline 2017 & $24 / 3$ & $22 / 4$ & $9 / 5-24 / 5$ & $8 / 6-25 / 6$ & $8 / 7-26 / 7$ & $22 / 8$ & $19 / 9$ & $19 / 10$ & \\
\hline
\end{tabular}

Water requirement $(\mathrm{WR})=\mathbf{E T}_{\mathbf{O}} \times \mathbf{K c} \times \mathbf{I E}$

ETo: Daily reference evapotranspiration ( $\mathrm{mm} /$ day)as shown in (Table7) can be calculated from the actual temperature, humidity, sunshine radiation and wind speed data, according to the FAO penman Monteith method (Allen et al.1998)
Kc: Crop coefficient values were taken from FAO(Allen et al., 1998) as shown in (Table7)

IE: Irrigation efficiency or water consumptive use $(85 \%$ of crop water requirements for irrigation by flooding system).

Table 7. Monthly crop coefficient $(\mathrm{Kc})$, evapotranspiration values $\left(\mathrm{Et}_{\mathbf{0}}\right)(\mathrm{mm} / \mathrm{day})$ of different treatment for Flame Seedless grapevines.

\begin{tabular}{lcccccccc}
\hline Treatments & Mar & Apr & May & Jun & Jul & Aug & Sep & Oct \\
\hline Kc & 0.28 & 0.22 & 0.18 & 0.16 & 0.18 & 0.19 & 0.22 & 0.34 \\
$\mathrm{Et}_{\mathrm{o}} \mathrm{mm} /$ day & 2.9 & 2.3 & 1.89 & 1.68 & 1.86 & 2.00 & 2.28 & 3.55 \\
Etc $\mathrm{mm} /$ day & 0.58 & 0.46 & 0.38 & 0.34 & 0.37 & 0.4 & 0.46 & 0.71 \\
\hline
\end{tabular}

\section{1-Bud behavior}

a- Bud burst:

Number of burst bud was counted one month after bud burst the percentage of bud burst were calculated as follows according to Bessis (1960).

$$
\text { Bud burst } \%=\frac{\text { No of bursted buds per vine }}{\text { Total buds per vine }} x 100
$$

\section{b-Bud fertility:}

Number of clusters per vine were counted and divided by the total number of buds and the fertility was calculated as follows according to Bessis, (1960).

$$
\text { Bud fertility } \%=\frac{\text { No of clusters per vine }}{\text { No of Total buds left at winter pruning }} \times 100
$$

\section{2-Vegetative growth parameters}

At veraison stage, the following morphological determinations were carried out on 4 shoots / the considered vine. Vegetative growth parameters were taken from non-bearing shoots

a- Average shoots length $(\mathrm{cm})$.

b- Average number of leaves/shoot

c- Average leaf surface area $\left(\mathrm{cm}^{2}\right)$

Twenty leaves / vine were picked at veraison stage of the apical $6^{\text {th }}$ and $7^{\text {th }}$ leaves using a CI-203Laser Area-meter made by CID, Inc., Vancouver, USA.

\section{3-Yield and physical characteristics of cluster}

Harvesting indices (TSS\% and acidity \%) were weekly monitored from veraison stage till maturity when TSS reached about $16-17 \%$ according to Tourky et al. (1995).

a- Yield/vine was determined by multiplying number of clusters/vine by average cluster weight.

b- Average cluster weight (g)

c- Number of Cluster

d- Average cluster length $(\mathrm{cm})$

e- Average cluster width $(\mathrm{cm})$

5-physical characteristics of berries

a- Number of berries per cluster b- Average 100 berry weight (g)

c- Average cluster diameter $(\mathrm{cm})$

6- Chemical characteristics of berries

a- Total soluble solids (TSS \%) in berry juice using a hand refractometer,

b- Total titratable acidity (as tartaric acid \%) according to the Official Analysis Methods (A.O.A.C., 1980) and TSS / acid ratio.

c- Total anthocyanin of the berry skin $(\mathrm{mg} / 100 \mathrm{~g}$ fresh weight) was calculated according to (Husia et al., 1965).

\section{7- $N, P$ and $K$ content in the leaves:}

Twenty leaf petioles / vine were picked at verais on stage from leaves opposite to cluster were used for the determination of $\mathrm{N}, \mathrm{P}$ and $\mathrm{K}$ content in the leaves.

Nitrogen content was estimated in the obtained digests using micro-kjeldahl distillation method (A.O.A.C., 1975). Phosphorus content was determined, using colourimetric method according to Fiske and Subbarow (1925). Potassium content was determined, using flame photometer according to Brown and Lilleland (1946).

8- At growth cessation parameters:

a- Total carbohydrates contentof canes ( $\%)$ :

Total carbohydrates were taken from canes for next season and determined at winter pruning according to modified method of (Schaffer and Hartman, 1921).

b- Wood ripening :

Wood ripening was determined at the end of growth season as a parameter of canes ripening. Smith et al., (1956)

\section{c- Weight of pruning:}

It was carried out at the time of winter pruning.

9-Water use efficiency (WUE)

Water use efficiency was calculated according to Viets(1962). 
$\mathrm{Y}$ : yield $(\mathrm{K} / \mathrm{fed})$

\section{WUE $=Y / W U(K g / m 3)$}

WU: consumptive use ( $\mathrm{m}^{3} /$ season)

Statistical analysis :

The complete randomized block design was adopted for the experiment. The statistical analysis of the present data was carried out according to Snedecor and Cochran (1994). Average was compared using the new L.S.D. values at $5 \%$ level.

\section{RESULTS AND DISCUSSION}

\section{1-Bud behavior}

a- Bud burst \%:

Data obtained in Table (8) clearly show that a significant gradual decrease in bud burst percentage with irrigation $5000 \mathrm{~m}^{3} /$ Fadden in Flame seedless grapevines during in both seasons, while irrigation $4000 \mathrm{~m}^{3} /$ Fadden followed by $4000 \mathrm{~m}^{3} /$ Fadden gave significant increase of bud burst \% from other studied treatments. The present results are in the same trend with those mentioned by Abd EL-Mksoud (2009)who found that bud burst percentage of Thompson seedless grapevines decreased by increasing irrigation water levels.

b-Bud fertility\%:

Results presented in Table(8) show that bud fertility\% were significantly affected by different levels of irrigation in both seasons of study. Data indicated that vines irrigated with $4000 \mathrm{~m}^{3} /$ Fadden had significant values followed by vines irrigated with $4500 \mathrm{~m}^{3} /$ Fadden, $3500 \mathrm{~m}^{3} /$ Fadden and the $5000 \mathrm{~m}^{3} /$ Fadden(control)which had the lowest values in both seasons. These results, as a general trend, are in agreement with those of AlObeed, (2010)and El-Gendy,(2012)who reported that gradual increase in fruitful bud percentage of grapevine was in parallel with increasing the irrigation rate.

Table 8. Effect of different levels of irrigation on percentages of bud burst and bud fertility of Flame seedless grapevines during 2016 and 2017

\begin{tabular}{lcccc}
\hline \multirow{2}{*}{ Treatments } & \multicolumn{2}{c}{ Bud burst\% } & \multicolumn{2}{c}{ Bud fertility\% } \\
\cline { 2 - 5 } & $\mathbf{2 0 1 6}$ & $\mathbf{2 0 1 7}$ & $\mathbf{2 0 1 6}$ & $\mathbf{2 0 1 7}$ \\
\hline $5000 \mathrm{~m}^{3} /$ Fadden(Control) & 91.33 & 92.67 & 45.839 & 47.625 \\
$4500 \mathrm{~m}^{3} /$ Fadden & 92.33 & 94.33 & 54.160 & 57.732 \\
$4000 \mathrm{~m}^{3} /$ Fadden & 96.00 & 96.33 & 55.357 & 60.125 \\
$3500 \mathrm{~m}^{3} /$ Fadden & 89.67 & 90.67 & 52.982 & 55.946 \\
New LSD 5\% & 0.72 & 0.93 & 1.12 & 1.13 \\
\hline
\end{tabular}

2- Vegetative growth parameters, wood ripening and weight of pruning wood:

Data given in table (9)show that vegetative growth traits namely average shoot length, average leaves number per shoot and leaf surface area were significantly affected by different tested levels of irrigation in 2016 and 2017 seasons. The significant value were obtained by vines irrigation with $4000 \mathrm{~m}^{3} /$ Fadden followed by irrigation $4500 \mathrm{~m}^{3} /$ Fadden followed by $3500 \mathrm{~m}^{3} /$ Fadden, while control vines gave significant decrease of average shoot length, average leaves number per shoot and leaf surface area in both seasons. The obtained result are in harmony with those reported by Nadal and lampereave (2005),Behairy et al.(2009) reported that water stress decreased leaf surface area on grapevine and Mohamed et al. (2016)who stated that vegetative growth were significantly affected by different level of irrigation They found that vines irrigated with1.4EThad the highest values of these parameters followed by vines irrigated with 1.2 ET, while vines irrigated with 1.0 ET ranked the third position.

Regarding wood ripening and weight of pruning wood/ vine, the data in Table (9) reveal significant differences in irrigating application of Flame seedless grapevines cultivar. The significant values were obtained for vines irrigating with $4000 \mathrm{~m}^{3} /$ Fadden followed in increasing order by irrigating with $4500 \mathrm{~m}^{3} /$ Fadden and irrigating with $3500 \mathrm{~m}^{3} /$ Fadden, while irrigating with $5000 \mathrm{~m}^{3} /$ Fadden(control) gave significant decreased of wood ripening and weight of pruning values in both seasons. These result as general trend were in agreement with the conclusion given with Bravdo and Naor(1997) in Cabernet sauvignon cv., who reported that pruning weight was affected by irrigation due to a differential effect of irrigation on fruit bud differentiation and on vegetative growth .Yuste et al . (2005)found that pruning weight of vine increased with an increase in water availability. Abd El-Maksoud (2009) found that wood ripening coefficient decreased by increasing irrigation water.

Table 9. Effect of different levels of irrigation on shoot length, number of leaves/shoot, leaf area, wood ripening and weight of pruning/vine of Flame seedless grapevines during 2016 and 2017

\begin{tabular}{lcccccccccc}
\hline \multirow{2}{*}{ Treatments } & \multicolumn{2}{c}{$\begin{array}{c}\text { Shoot length } \\
\text { (cm) }\end{array}$} & $\begin{array}{c}\text { Number of } \\
\text { leaves/shoot }\end{array}$ & \multicolumn{2}{c}{$\begin{array}{c}\text { Leaf area } \\
\left.\mathbf{( c m}^{\mathbf{2}}\right)\end{array}$} & \multicolumn{2}{c}{$\begin{array}{c}\text { Wood } \\
\text { ripening\% }\end{array}$} & $\begin{array}{c}\text { Weight of } \\
\text { pruning/vine(kg) }\end{array}$ \\
\cline { 2 - 12 } & $\mathbf{2 0 1 6}$ & $\mathbf{2 0 1 7}$ & $\mathbf{2 0 1 6}$ & $\mathbf{2 0 1 7}$ & $\mathbf{2 0 1 6}$ & $\mathbf{2 0 1 7}$ & $\mathbf{2 0 1 6}$ & $\mathbf{2 0 1 7}$ & $\mathbf{2 0 1 6}$ & $\mathbf{2 0 1 7}$ \\
\hline $5000 \mathrm{~m}^{3} /$ Fadden & 182.33 & 190.33 & 30.33 & 34.33 & 138.77 & 140.97 & 82.33 & 90.67 & 2.20 & 2.13 \\
$4500 \mathrm{~m}^{3}$ /Fadden & 193.00 & 193.33 & 36.33 & 38.33 & 149.73 & 149.70 & 91.33 & 93.67 & 2.80 & 2.77 \\
$4000 \mathrm{~m}^{3} /$ Fadden & 195.00 & 201.00 & 38.33 & 42.00 & 152.17 & 153.23 & 94.00 & 95.33 & 3.07 & 3.10 \\
$3500 \mathrm{~m}^{3} /$ Fadden & 190.00 & 192.00 & 33.33 & 36.00 & 140.00 & 142.27 & 89.00 & 92.33 & 2.63 & 2.50 \\
New LSD 5\% & 1.13 & 1.21 & 1.57 & 1.77 & 1.1 & 1.2 & 1.12 & 1.20 & 0.15 & 0.23 \\
\hline
\end{tabular}


3-Yield and physical characteristics of cluster:

The obtained results in Table(10) clearly showed that yield and physical of cluster i.e. average cluster weight, cluster number, average cluster length and cluster width. All parameters significantly affected by different levels of irrigation in the both growing seasons. The significant values in terms of average cluster weight, clusters number, average cluster length and width obtained for the vine irrigation with $4000 \mathrm{~m}^{3} /$ Fadden followed by irrigation with $4500 \mathrm{~m}^{3} /$ Fadden and irrigation with $3500 \mathrm{~m}^{3} /$ Fadden compared with the control( $5000 \mathrm{~m}^{3} /$ Fadden $)$. These results seemed to be in harmony with the results mentioned by Ferreyra et al.(2006)disclosed that different irrigation water amounts were applied, between 40 and $100 \%$ crop evapotranspiration (ET).They found that Crimson seedless grapevine yield was increased as the irrigation water rates increased. Mohamed et al.(2016) who found that moderate water irrigation represented in vine irrigated with 1.0 ET had recorded the highest water use efficiency which it reflected in achieving an appropriate balance between yield and bunch quality attributes of flame seedless grapevines. The increase of cluster weight and yield observed in irrigation treatment can be interpreted in view of the fact these treatments led to the increase in photosynthetic rate of leaves then cluster enhanced.

Table 10. Effect of different levels of irrigation on yield and physical characteristics of cluster of Flame seedless grapevines during 2016 and 2017

\begin{tabular}{|c|c|c|c|c|c|c|c|c|c|c|}
\hline \multirow[t]{2}{*}{ Treatments } & \multicolumn{2}{|c|}{$\begin{array}{c}\text { Yield /vine } \\
(\mathrm{kg})\end{array}$} & \multicolumn{2}{|c|}{$\begin{array}{c}\text { No. of } \\
\text { clusters }\end{array}$} & \multicolumn{2}{|c|}{$\begin{array}{c}\text { Cluster weight } \\
\text { (g) }\end{array}$} & \multicolumn{2}{|c|}{$\begin{array}{c}\text { Cluster length } \\
(\mathrm{cm})\end{array}$} & \multicolumn{2}{|c|}{$\begin{array}{c}\text { Cluster width } \\
\text { (cm) }\end{array}$} \\
\hline & 2016 & 2017 & 2016 & 2017 & 2016 & 2017 & 2016 & 2017 & 2016 & 2017 \\
\hline $5000 \mathrm{~m}^{3} /$ Fadden & 10.95 & 12.26 & 25.67 & 26.67 & 426.67 & 460.00 & 19.30 & 20.33 & 16.00 & 16.33 \\
\hline $4500 \mathrm{~m}^{3} /$ Fadden & 14.63 & 15.94 & 30.33 & 32.33 & 482.67 & 493.33 & 22.97 & 23.10 & 16.67 & 17.17 \\
\hline $4000 \mathrm{~m}^{3} /$ Fadden & 15.81 & 18.85 & 31.00 & 33.67 & 510.00 & 560.00 & 23.47 & 24.13 & 16.83 & 17.84 \\
\hline $3500 \mathrm{~m}^{3} /$ Fadden & 13.45 & 15.03 & 29.67 & 31.33 & 453.33 & 480.00 & 21.53 & 21.93 & 16.27 & 16.60 \\
\hline New LSD 5\% & 0.71 & 0.93 & 0.54 & 0.96 & 11.34 & 12.22 & 0.41 & 0.94 & 0.12 & 0.22 \\
\hline
\end{tabular}

\section{4-Physical characteristics of berries:}

Data tabulated in Table (11) reveal that physical characteristics of grape berries expressed average number of berries per cluster, average 100 berry weight and average berry diameter were significantly affected by all different tested level of irrigation in both seasons, where found that the significant values of these parameters obtained from vine irrigation with $4000 \mathrm{~m}^{3} /$ Fadden followed by vines irrigated with $4500 \mathrm{~m}^{3} /$ Fadden, and $3500 \mathrm{~m}^{3} /$ Fadden, while vine irrigated with $5000 \mathrm{~m}^{3} /$ Fadden (control) gave significant decrease in this respect in both seasons. The present data are generally in line with those recorded by Gurovich (2002)who indicated that the weight of berry was influenced in apositive correlation when $75 \%$ ETcwas applied by trickle irrigation particularly when compared with 50\%ETc.Palma et al.(2000)found that water deficit is the best irrigation strategy to achieve equilibrium between vegetative and reproductive activity and good berry quality of vitisvinifera grapevines.

Table 11. Effect of different levels of irrigation on physical characteristics of berries of Flame seedless grapevines during 2016 and 2017

\begin{tabular}{lcccccc}
\hline \multirow{2}{*}{ Treatments } & \multicolumn{2}{c}{$\begin{array}{c}\text { No .of berries/ } \\
\text { cluster }\end{array}$} & \multicolumn{2}{c}{$\begin{array}{c}\text { Average 100 berries } \\
\text { weight(g) }\end{array}$} & $\begin{array}{c}\text { Average berry } \\
\text { diameter (mm) }\end{array}$ \\
\cline { 2 - 8 } & $\mathbf{2 0 1 6}$ & $\mathbf{2 0 1 7}$ & $\mathbf{2 0 1 6}$ & $\mathbf{2 0 1 7}$ & $\mathbf{2 0 1 6}$ & $\mathbf{2 0 1 7}$ \\
\hline $5000 \mathrm{~m}^{3}$ /Fadden & 219.00 & 220.00 & 208.33 & 214.00 & 14.33 & 15.50 \\
$4500 \mathrm{~m}^{3}$ /Fadden & 222.00 & 224.33 & 211.33 & 220.67 & 17.33 & 17.93 \\
$4000 \mathrm{~m}^{3}$ /Fadden & 228.33 & 238.67 & 216.67 & 227.67 & 18.33 & 19.33 \\
$3500 \mathrm{~m}^{3} /$ Fadden & 220.33 & 222.00 & 210.67 & 218.67 & 16.83 & 16.83 \\
New LSD 5\% & 1.12 & 1.52 & 0.64 & 1.00 & 0.92 & 1.00 \\
\hline
\end{tabular}

\section{5-Chemical characteristics of berries:}

The different berry characteristics are presented in Table (12). Obtained data indicated that vine irrigation with $4000 \mathrm{~m}^{3} /$ Fadden gave significant values on total soluble solids (TSS \%), TSS / acid ratio content and anthocyanin of berry skin and the least value of total treatable acidity $(\%)$

These results are in line with those previously stated by Liumi et al.(1999), Abd EL-Mksoud (2009)and Shellie,(2005)who investigated the effect of different levels of irrigation( 500,1300 or $2100 \mathrm{~m}^{3} /$ ha)on
Chardonnay grapevines. They found that TSS was decreased by increasing irrigation level. Moreover, Intrigliolo and castel (2015)found that Overall, irrigation did not significantly affect anthocyanin concentration and total phenolic content of the wines. However, irrigation reduced anthocyanin concentration a similar trend on the variable effect of irrigation among years could be observed for the color intensity of the wine. Nonetheless, irrigation decreased wine color on average over the 6 years. 
Aisha S. A. Gaser et al.

Table 12. Effect of different levels of irrigation on chemical characteristics of berries of Flame seedless grapevines during 2016 and 2017

\begin{tabular}{|c|c|c|c|c|c|c|c|c|}
\hline \multirow[t]{2}{*}{ Treatments } & \multicolumn{2}{|c|}{$\begin{array}{c}\text { TSS } \\
(\%)\end{array}$} & \multicolumn{2}{|c|}{$\begin{array}{c}\text { Acidity } \\
(\%)\end{array}$} & \multicolumn{2}{|c|}{$\begin{array}{c}\text { TSS/acid ratio } \\
\text { ( \%) }\end{array}$} & \multicolumn{2}{|c|}{$\begin{array}{c}\text { Anthocyanin } \\
\text { (mg/100g F.W.) }\end{array}$} \\
\hline & 2016 & 2017 & 2016 & 2017 & 2016 & 2017 & 2016 & 2017 \\
\hline$\overline{5000 \mathrm{~m}^{3} / \text { Fadden }}$ & 16.00 & 16.00 & 0.43 & 0.45 & 37.20 & 35.55 & 10.56 & 10.60 \\
\hline $4500 \mathrm{~m}^{3} /$ Fadden & 17.00 & 17.00 & 0.42 & 0.44 & 40.47 & 38.63 & 10.89 & 10.90 \\
\hline $4000 \mathrm{~m}^{3} /$ Fadden & 17.50 & 17.67 & 0.40 & 0.40 & 43.75 & 44.17 & 10.93 & 10.95 \\
\hline $3500 \mathrm{~m}^{3} /$ Fadden & 16.50 & 16.50 & 0.41 & 0.41 & 40.24 & 40.24 & 10.75 & 10.85 \\
\hline New LSD $5 \%$ & 0.44 & 0.48 & 0.03 & 0.06 & 0.21 & 0.22 & 0.02 & 0.04 \\
\hline
\end{tabular}

6-NPK content of leaves $(\%)$ and total carbohydrates (\%) of canes

Concerning content of N, P and Kin the leaves, the obtained data clear that significantly increased of $\mathrm{N}$, $\mathrm{P}$ and $\mathrm{K}$ content $\%$ when]irrigated with $4000 \mathrm{~m}^{3} /$ Fadden in both seasons of study followed by vines irrigated with $4500 \mathrm{~m}^{3} /$ Fadden comparing to irrigated at $5000 \mathrm{~m}^{3} /$ Fadden which had significantly decreased in this respect
Regarding total carbohydrates content (\%)it is evident from the obtained data in Table (13) there is a pronounced significant on the average total carbohydrates content in canes with using irrigation with $4000 \mathrm{~m}^{3} /$ Fadden. the present results were agreement with (EL-Gendy,2012 and Ali and Abd-ELMoniem, (2006)who found that the positively effect of irrigation treatments on total carbohydrates \% of canes significantly increase with increasing the amount of irrigation water content of total carbohydrates $\%$.

Table 13. Effect of different levels of irrigation on NPK content of leaves (\%) and total carbohydrates (\%) of canes of Flame seedless grapevines during 2016 and 2017

\begin{tabular}{lccccccccc}
\hline \multirow{2}{*}{ Treatments } & \multicolumn{3}{c}{$\begin{array}{c}\mathbf{N} \\
(\mathbf{\%})\end{array}$} & \multicolumn{2}{c}{$\begin{array}{c}\mathbf{P} \\
(\mathbf{\%})\end{array}$} & \multicolumn{2}{c}{$\begin{array}{c}\text { K } \\
(\mathbf{\%})\end{array}$} & \multicolumn{2}{c}{$\begin{array}{c}\text { Total carbohydrates } \\
(\mathbf{\%})\end{array}$} \\
\cline { 2 - 11 } & $\mathbf{2 0 1 6}$ & $\mathbf{2 0 1 7}$ & $\mathbf{2 0 1 6}$ & $\mathbf{2 0 1 7}$ & $\mathbf{2 0 1 6}$ & $\mathbf{2 0 1 7}$ & $\mathbf{2 0 1 6}$ & $\mathbf{2 0 1 7}$ \\
\hline $5000 \mathrm{~m}^{3} /$ Fadden & 2.31 & 2.32 & 0.29 & 0.30 & 2.02 & 2.03 & 24.88 & 25.83 \\
$4500 \mathrm{~m}^{3} /$ Fadden & 2.33 & 2.34 & 0.32 & 0.34 & 2.04 & 2.05 & 26.26 & 28.5 \\
$4000 \mathrm{~m}^{3} /$ Fadden & 2.36 & 2.40 & 0.35 & 0.37 & 2.06 & 2.07 & 27.82 & 30.07 \\
$3500 \mathrm{~m}^{3} /$ Fadden & 2.32 & 2.33 & 0.30 & 0.32 & 2.03 & 2.04 & 25.86 & 26.09 \\
New LSD 5\% & 0.01 & 0.03 & 0.01 & 0.02 & 0.01 & 0.02 & 0.23 & 0.24 \\
\hline
\end{tabular}

\section{7- Water use efficiency (WUE)}

Result presented in Table (14) showed that water use efficiency (WUE)was significantly affected by different levels of irrigation in 2016 and 2017 seasons of this study. It was found that vines irrigated with $4000 \mathrm{~m}^{3} /$ Fadden had significant values of this parameter followed by $4500 \mathrm{~m}^{3} /$ Fadden, while $5000 \mathrm{~m}^{3} /$ Fadden ranked the third position .On the other hand, vines irrigated with $3500 \mathrm{~m}^{3} /$ Fadden had significant decreased in both seasons. Zayan et al.(2016)revealed that significant values of WUE and WP were obtained from trees irrigated at level 3 compared to the control which gave the lowest values in both seasons.

Table 14. Effect of different levels of irrigation on water use efficiency(WUE) of Flame seedless grapevines during 2016 and 2017

\begin{tabular}{lcc}
\hline Treatments & $\mathbf{2 0 1 6}$ & $\mathbf{2 0 1 7}$ \\
\hline $5000 \mathrm{~m}^{3} /$ Fadden & 2.19 & 2.55 \\
$4500 \mathrm{~m}^{3} /$ Fadden & 3.18 & 3.44 \\
$4000 \mathrm{~m}^{3} /$ Fadden & 3.95 & 4.43 \\
$3500 \mathrm{~m}^{3} /$ Fadden & 3.93 & 4.39 \\
New LSD 5\% & 0.01 & 0.03 \\
\hline
\end{tabular}

\section{CONCLUSION}

From the previous results, it can be recommended that irrigation of Flame seedless grapevinesby $4000 \mathrm{~m}^{3} /$ Fadden $/$ seasons gave promoting shoot length, leaf surface area, leaves number, yield, cluster weight and berry weight as well as enhanced chemicals properties of berries, wood ripping, pruning wood weight, leaf minerals content, total carbohydrates in canes and will increasing farmer income.

\section{REFERENCES}

Abd El-Maksoud, M.M. (2009) Some new methods for saving irrigation water for grapevines. $\mathrm{PhD}$ Thesis, Institute of Environmental studies and research, Ain Shams University

Ali, M.A. and E.M. Abd-El Moniem (2006)Water requirements for Superior Seedless grapevines under desert Iand conditions. Egypt J. Appl. Sci., 21:643-661. 
Allen, R.; L.A. Pereira; D. Raes and M. Smith (1998)Crop evapotranspiration. Guidelines for computing crop water requirements, Irrigation and Drainage Paper 56, Food and Agric. Organization of the United Nations, Rome, Italy, PP: 300 .

AL-Obeed R.S.;H.A. Kassem and M.A. Ahmed (2010) Effect of grapevines varietal differences on bud fertility, yield and fruit quality under arid environments and domestic wastewater irrigation .Amer-Eur J. Agric .Env. Sci. 9(3):248-255.

A.O.A.C. (1975)Association of Official Analytical Chemists. $4^{\text {th }}$ ed Washington, DC B. PP. 832.

Anne, P.; C. Peter; C.Nicola and W. Rob, (2014)Management practices impact. Vine carbohydrate status to a greater extent than vine productivity. J. List.Frontplant.Sci-7-5.

A. O. A.C. (1980)Association of Official Analytical Chemists. $14^{\text {th }}$ ed Published by A O A C., Washington D C, USA

Behairy, Z.H.; M.M. Hegazi; M.N.N. Tourky and M.M. Abd EL-Maksoud (2009) Some New Methods for Saving Irrigation Water for Grapevines. In the proceedings of 60 IEC meeting and 5 Asian regional conference. New Delhi.

Bessis, R. (1960) Sur Differents Models Expression Quantitative Delafertilité chez la vigneAca p.p. 828-882.

Bravdo, B. and Y. Noar (1997)Irrigation management and fertigation to optimize grape composition and vine performance Acta-Horticulturae. (206):49-67.

Brown, J.D. and O. Lille land (1946) Rapid determination of Potassium and Sodium in plant material and extracts by flame photometer.

Chaves, M.M.; O. Zarrouk; R. Francisco; J.M. Costa; T. Santos; A.P. Rodrigues and M.L. Lopes (2010) Grapevine under deficit irrigation: hints from physiological and molecular data. Annals of Botany 105, 661-676.

EL Gendy R .S. S. (2012) Water requirements of grafted grape vine under Desert land conditions. J.Hort. Sci. and Ornam. Plants 4(4):345-364.

Ferreyra, R.; G. Selles; H. Silva; R. Ahumada; I. Munoz and V. Munoz (2006)Effect of applied water on water relations and productivity of Crimson Seedless table grapes. Pesquisa Agropecuaria Brasileira, 41:1109-1118.

Fiske, C.H. and Y. Subbarow (1925)The calorimetric determination of phosphourus. J. Biol. Chem., $66: 375$.

Gurovich, L. A. (2002) Irrigation Scheduling of table grapes under drip Irrigation: an opproach for saving irrigation water energy costs Inchile. Inter. water Irrigation, 22:44-50.

Husia, C. L.; B. S. Luh and C. D. Chichester (1965)Anthocyanin in free stone peach. J. Food Sci., 30: 5-12.
Intrigliolo, D. S and J. R. Castel (2015)Effect of irrigation on the performance of grapevine cv. Tempranillo in Requena, Spain. Article in Americ. J. of Enology and Viticulture.59:1.

Liumi, C.S.; D, Antonacci; A. Caputo; G. Masi and F. Giorgessi (1999)The importance of irrigation and training systems with down wards oriented shoots on the management of viticulture quality in warm arid environments. (Hort. Abst., 69:9355).

Lopeld, C.M.;T.P. Santos; A. Monteiroa; A. Rodrigues; M.L. Costa and J.M., Chaves (2011) Combining cover cropping with deficit irrigation in a Mediterranean low vigor vineyard. Scientia Horticulturae 129, 603-612.

Lovisolo, C.;A. Schubert; E. Peterlunger and S. Ferraris (2000) Sap flow and stem conductivity of potted water stressed grapevines. Acta-Horticulturae. (526):187-191.

McCarthy, M.G.; B.R. Loveysand P.R. Dry(2000) Regulated deficit irrigation and partial root zone drying as irrigation management techniques for grapevines. In Deficit Irrigation Practices.Water Reports 22. FAO, Rome.

Mohamed, G.A.; M.Z. Abd EL-Wadoud and G.H. Sabry (2016)Effect of water regime on growth, yield and fruit quality of Flame seedless grapevines. Egypt. J. of Appl. Sci., 31(11)

Nadal, M. and M. Lampreave (2005)Influence of moderate irrigation and plant age on growth, water potential, photosynthesis and composition of Tempranillo wines. In the proceedings of the XIV Intenational GESCO Viticulture Congress, Geisenheim, Germany, pp:194-200.

Nelson, N. Somogi (1944)A photometric adaptation of the somogyi method for the determination of glucose. Biological Chemistry, College of Medicine, University of Cincinnati, Cincinnat (Received for publication, February 3, 1944).

Palma, L. D.;V. Novelloand R. D. Lorenzo (2000) Irrigation requirement of Vitisvinifere L. in hot arid environments .Irrigazione -e- Drenaggio. 47(4):21-29.CAB Abstracts (1980-2007).

Plummer, D.T. (1971)An introduction to practical biochemistry MSc. Graw. Hill Book company (UK) Limited. Maidenhead, Berkshire. England.

Schaffer, P.A. and A.F. Hartman (1921)Theidomet determination of copper and its use in sugar analysis. J. Bio.Chem.45:349-364.

Selles V.S.;G. E. R. Ferreyra; W. G. Contreras and B. R. Ahumada (2004)Effect of three irrigation frequencies applied by drip irrigation over table grapes international water and irrigation. Hort. Abs. (74) No.10).

Shellie, K. (2005)Vine water stress severity in Vitisvinifera L. cv. Merlot: impact on yield components, berry and wine composition. XIV International GESCO Viticulture Congress, Geisenheim, Germany, 534-539.CAB Abstracts (1980-2007). 
Smith, F.;M. A. Gilles; J. K. Hamilton and Gedess, P.A. (1956)Colorimetric method for determination of sugar and related substan. Anal. Chem., 28: 350 .

Snedecor, G.W. and W.G Cochran(1994) Statistical Methods. $8^{\text {th }}$ ed., Journal of Education and Behavioral Statistics, 19 (3):304-307.

Tourky, M.N.;S.S. El-Shahatand M. H. Rizk (1995)Effect of Dormex on fruit set, quality and storage life of Thompson seedless grapes (Banati grapes) J. Agric. Sci., Mansoura Univ., 20(12): 5139-5151.

Viets, F.G.(1962)Fertilization and efficient of water. Advances in Argon, 14:223-264.
Yuste, J.;J. LAsenjo; M. VAlburquerque and J.A. Rubio (2005) Relationships among physiology, growth and production as affected by water regime and vinespacing of 'Tempranillo' grapevines. Proceedings of the $7^{\text {th }}$ International Symposium on Grapevine Physiology and Biotechnologypp 343-348

Zayan, M. A.; R. A. Sayed; A. R. El-Shereif and H. M. A. EZawily (2016)Irrigation and fertilization programs for "Washington navel" orange trees in sandy soil under desert climatic conditions. J. Agric. Res. Kafr EL-Sheikh Univ., Vol., 42(2):210-233.

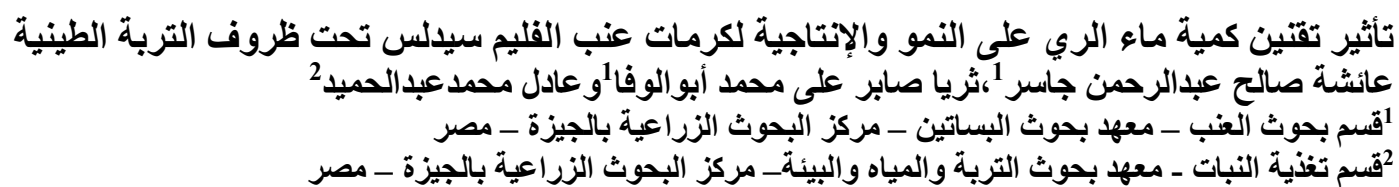

أجرى هذا البحث لمدة ثلاثة مواسم متتالية (2015، 2016، 2017) بهدف تحديد الاحتياجات المائية على النمو والمحصول

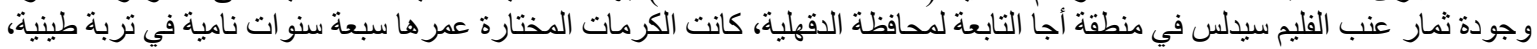

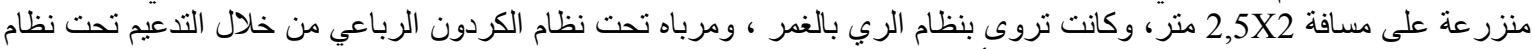

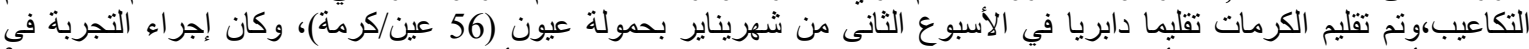

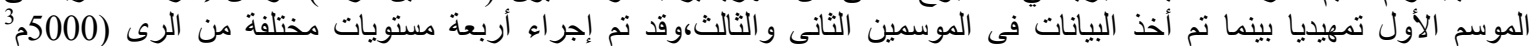

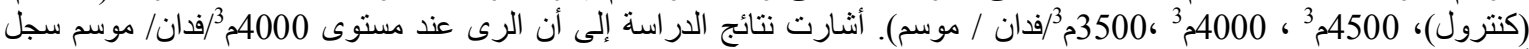

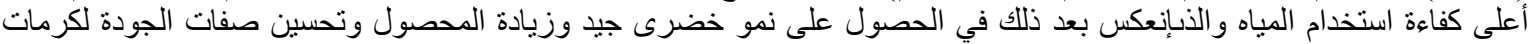

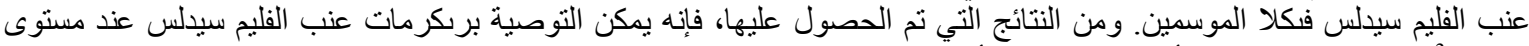

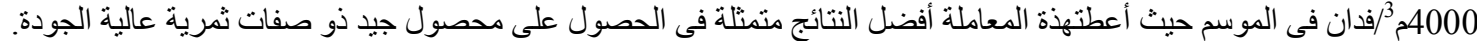

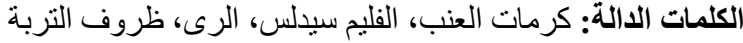

